\title{
Return Anomalies "Disposition Effect and Momentum": Evidence from the Egyptian Stock Market
}

\author{
Ahmed M. Sakr ${ }^{1}$, Mohamed A. Ragheb ${ }^{1}$, Aiman A. Ragab ${ }^{1} \&$ Rabab K. Abdou ${ }^{1}$ \\ ${ }^{1}$ College of Management and Technology, Arab Academy for Science Technology and Maritime Transport, \\ Alexandria, Egypt \\ Correspondence: Mohamed A Ragheb, College of Management and Technology, Arab Academy for Science \\ Technology and Maritime Transport, Alexandria, Egypt. E-mail: raghebmm@yahoo.com
}

Received: November 7, 2012

Accepted: December 19, 2013 Online Published: January 23, 2014

doi:10.5539/ijef.v6n2p181

URL: http://dx.doi.org/10.5539/ijef.v6n2p181

\begin{abstract}
Purpose: The persistence of momentum in stock returns across both developed and emerging markets and the challenges that it poses against the Efficient Market Hypothesis created a need to explain its existence. Grinblatt and Han (2005) formulated a model to explain momentum using a well documented behavioral bias which is the Disposition effect. The focus of this paper is to analyze whether disposition effect drives momentum in the Egyptian stock market as one of the growing emerging markets that faces a considerable lack in behavioral studies.
\end{abstract}

Design/methodology/approach: The study is quantitative in nature studying whether disposition effect drives momentum using a sample of 48 companies through the time period 2004-2010. The relation between disposition effect and momentum will be analyzed empirically using Fama Macbeth cross-sectional regression.

Findings: Results show that there is no momentum in stock returns in the Egyptian stock market. In addition they show that disposition effect does not drive momentum in the Egyptian stock market as there is no significant relation between expected return and capital gain overhang. The results reveal useful insights about the Egyptian stock market that can be of beneficial use for both practitioners and academics.

Research limitations/implications: Limited number of active companies in the Egyptian stock market as well as the limited available historical data poses some restrictions in the implementation of Fama Macbeth regression and the calculation of reference price. In addition analyzing the profitability of momentum strategies across different market states may be required to provide complete picture about momentum in the market.

Practical implications: Relative strength strategies do not earn abnormal return in the Egyptian stock market, so practitioners are not advised to follow such strategies. In addition more advanced market mechanisms should be applied in the Egyptian stock market to improve its efficiency as well as increase the speed of information dissemination in the prices.

Originality/value: Detailed analysis of literature review reveals a significant gap in academic studies about the Egyptian stock market. This paper aims to fill this gap by analyzing whether there is momentum in stock returns and whether disposition effect drives momentum in the Egyptian stock market that differs from other markets where Grinblatt and Han (2005) has been previously applied and hence this provides an out of sample test of the model.

Keywords: momentum, disposition effect, prospect theory/mental accounting framework, Egyptian stock market

\section{Introduction}

An efficient market is a market where security prices fully reflect all the available information (Fama, 1970). However, despite the wide popularity of EMH after its conception, its theoretical foundations and empirical evidence supporting its existence have been challenged in the last few decades (Shleifer, 2000). The overwhelming empirical predictions of the EMH anticipate that prices should react quickly and correctly to the news; hence investors who receive the news late will not be able to profit from this information, also prices should neither overreact nor under-react to information, and thus no trends nor price reversals should be observed in the market. However these predictions have been strongly challenged. 
Given the premises of EMH stated above, the predictability of stock prices is considered as one of the challenges facing EMH. Several researchers have proved that investors can make profit by simply observing past prices; Debondt and Thaler (1985) found that there is long term price reversal over 3-5 years and they linked their results to the tendency of stock prices to overreact to information and this enables investors to achieve abnormal profits from pursuing contrarian strategies. While Jegadeesh (1990) and Lehmann (1990) found evidence supporting the existence of short term price reversal over a period of one week to one month, however since these strategies are transaction intensive and are based on short term price movements, the abnormal profits achieved may be due to short term price pressure or lack of liquidity in the market rather than overreaction (Jegadeesh \& Titman, 1993).

The most striking evidence against the EMH, that has attracted the attention of both academics and practitioners, is the existence of intermediate momentum in stock return that was firstly observed by Jegadeesh and Titman (1993) as the persistence in the returns of stocks over horizons between three months and one year. Upon their article several studies have been carried out which proved that the observed momentum return is robust and observable in different markets and time periods (Rouwenhorst, 1998; 1999). This in turn rules out the possibility that momentum in returns is due to data snooping. Therefore academic interest has shifted towards analyzing the sources of momentum; that ranged between risk based and behavioral explanation (Jegadeesh \& Titman, 1993; 2001; Daniel et al., 1998; Barberis et al., 1998; Hong \& Stein, 1999).

Among the behavioral models emerged to explain momentum is Grinblatt and Han (2005) model that uses a well documented behavioral anomaly which is the disposition effect. Shefrin and Statman (1985) defined disposition effect as the tendency of investors to realize their winning transactions quickly and hold their losing transaction for a long time period. A large array of explanations have emerged to determine why investors exhibit disposition effect, however prospect theory/mental accounting framework is considered as the best and most sufficient explanation (Grinblatt \& Han, 2005; Frazzini, 2006)

The widespread persistence of disposition investors created academic interests in discovering their impact on security prices. Given this inspiration, Grinblatt and Han (2005) studied how the existence of disposition investors distorts the rational demand function for the stocks. They found that the tendency of disposition investors to sell (keep) winners (losers) leads to slow reaction to good (bad) news, as a result stocks will under-react to news and a spread between the fundamental value and the market prices will arise. As this mispricing gets corrected, return predictability will arise and profits can be made from momentum strategies.

\section{Research Objectives and Importance}

The aim of this study is to analyze whether disposition effect using prospect theory/ mental accounting framework drives momentum in the Egyptian stock market.

This overall aim can be divided into the following objectives:

1) To discover whether there is momentum profit in the Egyptian stock market.

2) To analyze if disposition effect drives momentum in the Egyptian stock market.

\subsection{The Academic Perspective}

The value of this study emerges from the literature review that provides a meaningful analysis of the existence of momentum in stock returns in different markets to show the persistence of the phenomenon across markets. From this analysis, the conflicting results about the existence of momentum in emerging markets will emanate; this will add value to this study by focusing on the Egyptian stock market which is one of the growing emerging markets to determine whether there is significant momentum profit in the market. In addition despite the overwhelming literature coverage of momentum in stock returns in different markets, there is a substantial lack in studies analyzing momentum in the Middle East in general and the Egyptian stock market in particular. In addition the Egyptian stock market is different from other markets where Grinblatt and Han (2005) model has been previously applied and hence this study provides an out of sample test for the model.

\subsection{The Practical Perspective}

Empirically, this study aims to fill the gap identified from literature review by focusing on the Egyptian stock market during the period 2004-2010, as one of the growing emerging markets that has passed by different phases which makes it an interesting field of study, however it has not yet reached the level of sophistication and efficiency of developed markets. This may lead to different return patterns compared to developed markets. In addition there is a prevalent difference in the quality of information between developed and emerging markets. Since developed markets have stronger property rights as well as better corporate governance which encourage arbitrage-based trading on fundamentals. 
While in emerging markets noise-based trading is more prevalent as investors are more likely to exhibit irrationality and cognitive biases. Hence anomalies such as momentum may be different in magnitude and persistence between developed and emerging markets (Ansari \& Khan, 2012). Finally the results are of beneficial use to both individual and professional investors in setting their investment strategies that can make use of the return patterns available in the market, in addition the results can give implications about the efficiency of the Egyptian stock market and reveal some facts about the Egyptian stock market that has suffered from a considerable lack in academic studies.

\section{Momentum}

Predictability of stock return has received substantial coverage in finance literature as one of the major challenges to the EMH. The tendency of past winners to continue to outperform past losers over intermediate term documented by Jegadeesh and Titman (1993) has attracted the attention of both practitioners and researchers and intensified the challenges posed against EMH. In addition Momentum strategies that tend to benefit from the existing momentum in stock returns, by buying winners and selling losers, are common between professional investors and constitute a well organized investment style in many markets (Chan et al., 1996). Hence this makes momentum one of the most commonly analyzed and puzzling anomalies in finance literature (Lewellen, 2002).

Upon its documentation by Jegadeesh and Titman (1993) many articles emerged to analyze whether it is persistent in different markets and time periods. Rouwenhorst (1998) found evidence supporting the existence of momentum strategies in 12 European countries during the period 1980-1995, additional evidence has been obtained from the Australian market (Hurn \& Pavlov, 2003). In addition Griffin et al. (2003) measured momentum profits internationally, by taking samples from all the continents, and the results showed that momentum profits are significant in all regions except Asia with emerging market showing weaker profits compared to developed ones.

However the results of emerging markets seem somehow mixed. On the one hand Rouwenhorst (1999) indicated that there is evidence of significant momentum profits in 6 out of the 20 emerging markets studied over the period 1982 to 1997. While Van der Hart et al. (2005) studied the success of momentum strategies in emerging markets using data drawn from S\&P/IFC Emerging Markets database, and they found that momentum strategies yield significant returns over the period December 1998-June 2004.

On the other hand, Hameed and Yuanto (2002) studied momentum strategies in six Asian countries and they found that none of the unrestricted momentum strategies that involve ranking stocks based on their past J-months return yield significant profits. Additionally, in China there was evidence supporting the existence of contrarian rather than momentum profits (Wang, 2004; Cao, 2010). This contradiction in the results about emerging markets adds value to this study by focusing on the Egyptian stock market as a growing emerging market.

\section{Disposition Effect}

The tendency of investors to sell their winning stocks too early and keep their losing stocks too long was first clarified by Shefrin and Statman (1985). This behavioral anomaly has attracted researchers to prove its existence in different markets, and among different investors. Among those researchers was Odean (1998) that studied 10,000 accounts at a large brokerage firm in US from 1987 to 1993 and the results proved that investors realize gains more readily than losses. In addition Shapira and Venezia (2001) supported the existence of disposition effect in Israel for both professional and amateur investors although it was stronger for amateur ones which shows that disposition effect decreases as training and experience increases and this is supported by the results of Dhar and Zhu (2006).

Given the above evidence, the existence of disposition effect cannot be debated. However its source remains a debatable area, where no consensus has been reached about the best explanation. Prospect theory, mean reversion, avoiding regret and seeking pride are among the most common explanations for disposition effect. However Grinblatt and Han (2002) and Frazzini (2006) stated that prospect theory/mental account framework provides a leading explanation for disposition effect and momentum in stock returns.

Under prospect theory/mental accounting framework the investors tend to separate different gambles into different accounts and apply prospect theory to each account separately, where the interactions between accounts is ignored. The different risk attitudes, implied from the S-shaped utility function that is concave in the domain of gain and convex in the domain of loss, towards different gambles are driven by whether the stock achieved a capital gain or loss. As a result, risk aversion (seeking) towards winning (losing) transactions leads to the observed disposition effect.

\section{Disposition Effect and Momentum}

Behavioral finance emerged to provide explanations for the observed anomalies in the financial markets that 
traditional financial theories proved to be incapable or insufficient to justify their existence. Momentum in stock returns is considered one of the common return anomalies that different behavioral models emerged to explain. Grinblatt and Han (2005) have developed a theoretical model and a number of testable 1mplications to explain how disposition effect can drive momentum in stock prices.

The existence of disposition investors distorts the rational demand function as a result of their tendency to sell winners and keep losers. The demand distortion induced by disposition investors affects equilibrium prices and leads to under-reaction to news. If good news has been revealed about a stock, this leads to capital gains for disposition investors. Consequently risk aversion at gain domain pushes the investors to realize the gains achieved quickly before prices fall. This excess selling pressure leads to under-reaction to good news i.e. stocks that have capital gains tend to be undervalued at equilibrium. While if bad news has been announced about the stock, this leads to capital losses for disposition investors. Their tendency to keep losers leads to sluggish response to the bad news; thus stocks that have capital losses tend to be overvalued at equilibrium. As the resulted under-reaction gets corrected, momentum in stock returns will emerge and investors can benefit from pursuing relative strength strategies.

Grinblatt and Han $(2002 ; 2005)$ explained that the profitability of momentum strategies is due to the positive relationship between expected return and capital gain as measured by the difference between the market price and the reference price. As stocks that have achieved capital gain (if the market price is higher than reference price) tend to be winners and vice versa. While past returns are only noisy proxy for behavioral variables, like capital gains, and are poorer predictors of expected returns than capital gains proxies. Since the pattern of past returns combined with past trading volume determine whether the stock has achieved capital gains and losses; thus unrealized capital gain is a better predictor of future returns compared to past return.

In order to measure whether this relation holds empirically, it is important to determine the reference price in an accurate manner as it is the basis against which the investor determine if he/she is making a gain or loss by comparing it to the market price to calculate the capital gain, which is a critical variable that help to determine expected changes in prices. Since it is difficult to identify who are the disposition investors and determine their reference prices exactly; Grinblatt and Han (2005) developed an estimation of aggregate cost basis for all the outstanding shares to be used as the reference price. The following equation shows the calculation of the reference price where $\mathrm{V}_{\mathrm{t}-\mathrm{n}}$ shows the stock turnover rate at date $\mathrm{t}-\mathrm{n}$, and the term in parenthesis represents weights where all weights sum up to one. The weights represent the probability that the stock has been purchased on date $t-n$ and has not been traded since then.

For empirical analysis the calculation of reference price will be shorten to three years, and although the three years is an arbitrary cutoff point but it will allow for a consistent manner in calculating the reference price. Grinblatt and Han (2002) mentioned that historical prices have negligible impact on the reference price, as the survival probability for a historical price declines geometrically with the passage of time. Thus using a three year cutoff period will not affect the results since the more recent prices have the greatest impact on the reference price.

$$
\mathrm{Rt}=\frac{1}{k} \sum_{n=1}^{1 E \epsilon}\left(V t-n \prod_{\tau=1}^{n-1}[1-V t-n+\tau] P t-n\right.
$$

Where $\mathrm{k}$ is the scaling constant that makes the fractions sum to one,

$$
\mathrm{K}=\sum_{n=1}^{1 \mathrm{~B} 6}\left(V t-n \prod_{\tau=1}^{n-1} L 1-V t-n+\tau \Gamma\right.
$$

In order o determine whether disposition effect drives momentum, an important variable should be calculated, which is the capital gain overhang. If disposition effect drives momentum then controlling for this variable, the observed momentum will disappear. Capital gain overhang is used as a proxy for the aggregate unrealized capital gain, and it is represented by the difference between the market price and the aggregate cost basis (reference price). The calculation of capital gain overhang is represented by the following equation:

$$
\mathrm{gt}=\frac{P t-1-R t}{P t-1}
$$

In order to account for the confounding market microstructure effect, such as bid ask bounce, in this model lag one week market price Pt-1 will be used instead of Pt (Grinblatt \& Han, 2005).

\section{Research Methodology}

This study is quantitative in nature studying whether there is momentum in stock returns in the Egyptian stock 
market and whether disposition effect drives momentum using Fama Macbeth (1973) cross-sectional regression.

\subsection{The Egyptian Stock Market}

The Egyptian stock market is one of the oldest in the world, and it comprises two exchanges that have been recently integrated allowing investors to have access to stocks listed on both of them; Alexandria stock exchange, which was established in 1888, and Cairo stock exchange that was established in 1903. It was the fifth most active stock exchange worldwide in 1940s, prior to the nationalization of industry and choosing the central planning policies in the early 1950s. These policies led to a significant reduction in the market activities, and as a result the market remained largely dormant throughout the 1980s. The market recovered again in the early 1990s after the 40 years stagnation period, and since then it has been considered the premier capital market in the Middle East and North Africa that best serves its stakeholders (Mecagni \& Sourial, 1999).

Table 1 summarizes some indicators about the Egyptian stock market for the time period 2004-2010. The first aspect about the Egyptian stock market is the decline in the number of listed firms from 2004 till 2010, which may be due to the emergence of strict delisting and disclosure rules. Another aspect that should be emphasized is related to the type of investors in the market. The percentage of total value traded by retail investors shows a consistent increase between years 2004-2009, in addition retail investors control between $53 \%-66 \%$ of the total value traded in the market and this indicates that that there is a considerable part of market transactions controlled by them which means that they have a significant impact on the market.

Table 1. Market summary

\begin{tabular}{llllllll}
\hline Indicators & $\mathbf{2 0 0 4}$ & $\mathbf{2 0 0 5}$ & $\mathbf{2 0 0 6}$ & $\mathbf{2 0 0 7}$ & $\mathbf{2 0 0 8}$ & $\mathbf{2 0 0 9}$ & $\mathbf{2 0 1 0}$ \\
\hline Listed companies & 795 & 744 & 595 & 435 & 373 & 306 & 212 \\
Number of traded companies & 503 & 441 & 407 & 337 & 322 & 289 & 211 \\
Percentage of retail Investors & $54 \%$ & $53 \%$ & $60 \%$ & $61 \%$ & $66 \%$ & $63 \%$ & $48 \%$ \\
\hline
\end{tabular}

Source: Cairo and Alexandria Stock Exchange Annual Reports.

The prevalence of retail investors gives some insights about the market; since they are more exposed to behavioral biases include among others herd-behavior, chasing rumors, and disposition effect. The prevalence of such biases in the market causes distortion in demand functions as well as stock prices (Grinblatt \& Han, 2005). However, as can be seen there is a substantial decline in the percentage of retail investors in year 2010, these changes can be of beneficial use to the market and its efficiency by increasing the number of institutional investors who are more experienced and less exposed to different behavioral biases.

\subsection{Data Collection}

The data used in this study consists of weekly data about adjusted closing prices, trading volume in shares, the total number of shares outstanding, and finally market capitalization for the time period May 2004-December 2010. All the data was collected from "Egypt for information Dissemination" "EGID" which is a joint venture company between the Egyptian Exchange-EGX and NasdaqOMX. The data obtained is used to calculate the weekly returns for each stock, past cumulative short, intermediate and long horizon returns, average weekly turnover (trading volume divided by the number of shares outstanding), logarithm of market capitalization, reference price and capital gain overhang.

Some issues should be elaborated about the data; First, the limited number of companies that are used in this study compared to previous studies that analyzed the relationship between disposition effect and momentum (Grinblatt \& Han, 2002; 2005; Frazzini, 2006); this is mainly due to the limited number of companies listed in the Egyptian stock market. In addition in order to calculate the reference price in an accurate manner at least three years of historical data should be available for each stock; so stocks that do not have data for at least three years will be excluded from the sample.

Finally stocks whose prices are less than 3 L.E. will also be excluded to avoid unnecessary noise in the calculation of returns as well as small illiquid stocks that may influence the results (Conrad \& Kaul, 1993; Jegadeesh \& Titman, 1993). By applying the above criterion, the sample will consist only of 48 stocks for the time period from May, 2004 to December, 2010 making up 364 weeks. In the following subsection detailed description of the variables will be presented. 


\subsection{Variables Description}

The dependent variable is the weekly return of each stock $\left(\mathrm{r}_{\mathrm{t}}=\frac{p t-p t-1}{p t-1}\right)$. The independent variables include the past returns, size, volume and capital gains and losses variables. The past cumulative returns $\left(\mathrm{r}_{\mathrm{c}}=\prod_{i=1}^{n}\left(1+r_{i}\right)-1\right)$ for three main horizon; short horizon $\left(\mathrm{r}_{-4:-1}\right)$, intermediate horizon $\left(\mathrm{r}_{-52:-5}\right)$, and long horizon $(\mathrm{r}-156:-53)$ are used to control for the return effects as mentioned in Debondt and Thaler (1985), Jegadeesh and Titman (1993) and Lehmann (1990). To control for the return premium for the size effect, the logarithm of the market capitalization is used to proxy for the firm size. Another variable is the average weekly turnover (weekly volume divided by the number of outstanding shares) over 52 weeks $\left(\mathrm{V}_{\mathrm{t}-52: \mathrm{t}-1}\right)$ to control for the volume effect (Lee and Swaminathan, 2000). The last variable is the capital gains and losses $\left(\mathrm{g}_{\mathrm{t}-1}\right)$ to show whether the disposition effect drives momentum in stock returns. The regression equation will be as follows:

$$
r=a_{0}+a_{1} r_{-4:-1}+a 2 r_{-52:-5}+a_{3} r_{-156:-53}+a_{4} V_{t-52:-1}+a_{5} S_{t-1}+a_{6} g_{t-1}
$$

The two variables of interest in the above regression equation are the coefficients of intermediate returns and capital gain overhang as well as their time series t-statistics. As according to Grinblatt and Han (2002) model, the coefficient of intermediate return should be insignificant after the inclusion of capital gain overhang as a regressor. So the significance of the coefficient of both variables is given considerable attention to analyze the relationship between disposition effect and momentum.

\subsection{Research Question}

The main aim of this study is to analyze whether disposition effect drives momentum in the Egyptian stock market. This aim can be translated into the following research question:

$R Q 1$. Is there momentum in stock return in the Egyptian stock market? Does disposition effect drive momentum in the Egyptian stock market?

\subsection{Research Hypotheses}

The above research question provides the basis to develop the main hypotheses in order to analyze whether disposition effect drives momentum in the Egyptian stock market.

Hypothesis 1: There is a positive relationship between the past returns and the unrealized capital gains.

Hypothesis 2: The unrealized capital gains or losses variable is positively related to the expected returns.

Hypothesis 3: Stocks exhibit intermediate horizon momentum effect- past winners will continue to be winners while past losers will continue to be losers.

Hypothesis 4: The intermediate horizon momentum effect disappears when the capital gains overhang is controlled for.

\section{Research Analysis, Findings and Discussion}

The Statistical Analysis Software (SAS) package was used for the quantitative analysis and application of the tests used in this study which are: summary statistics to describe the data and Fama Macbeth cross-sectional regression to test whether the aforementioned hypotheses are supported.

\subsection{Summary Statistics}

Summary statistics aims at describing the main variables that will be used in the regression analysis which are short-term cumulative return $\left(\mathrm{r}_{-4:-1}\right)$, intermediate term cumulative term $\left(\mathrm{r}_{-52:-5}\right)$, long term cumulative return $\left(\mathrm{r}_{-156:-53}\right)$, average weekly turnover over the prior 52 weeks $(\mathrm{V})$, logarithm of market capitalization measured at the beginning of week $\mathrm{t}(\mathrm{S})$, and finally unrealized capital gain $(\mathrm{g})$ measured as the difference between the market price and the reference price. Table 2 represents the time series means and standard deviations of the cross-sectional averages of the main variables, along with the time series means of their $10^{\text {th }}, 50^{\text {th }}$ "median" and $90^{\text {th }}$ percentiles. 
Table 2. Time series average of summary statistics

\begin{tabular}{lllllll}
\hline & $\mathrm{r}_{\mathrm{t}-4:-1}$ & $\mathrm{r}_{\mathrm{t}-52:-5}$ & $\mathrm{r}_{\mathrm{t}-156: 53}$ & $\mathrm{~V}_{\mathrm{t}-52:-1}$ & Size & Capital Gain \\
\hline Mean & 0.024012 & 0.3575123 & 1.183992 & 0.011653 & 8.856288 & -0.06415 \\
Median & 0.0052 & 0.1677 & 0.51955 & 0.002682 & 8.824927 & 0.1198 \\
Standard Deviation & 0.178828 & 1.1061879 & 3.085401 & 0.042845 & 0.753197 & 0.730644 \\
$10^{\text {th }}$ percentile & -0.1522 & -0.413 & -0.3661 & 0.000429 & 7.968483 & -0.9213 \\
$90^{\text {th }}$ percentile & 0.2063 & 1.1692 & 2.7586 & 0.022798 & 9.859214 & 0.5645 \\
\hline
\end{tabular}

The time series means (medians) of short, intermediate and long cumulative return over the sample period form 2004-2010 are $0.024(0.0052), 0.3575$ (0.1677), and 1.184 (0.5196) respectively. The means of cumulative returns are positive; this can be attributed to the development phases that the Egyptian stock market witnessed during the sample period, in addition to the economic growth witnessed during this period with the GDP growth percentage increasing from $4.1 \%$ to $7.2 \%$ from 2004 to 2008 which created a positive sentiment in the economy that had its positive impact on the Egyptian stock market (Egyptian Economic Monitor, 2010). The time series means (medians) of weekly turnover, size and capital gain overhang are 0.0117 (0.0027), 8.856 (8.825), and -0.06415 (0.1198) respectively. The mean of capital gain turned out to be negative which gives an indication that on average investors achieved capital losses during the sample period. The time series means of the $10^{\text {th }}, 90^{\text {th }}$ percentiles of the capital gain overhang are -0.9213 , and 0.5645 respectively.

\subsection{Fama Macbeth (1973) Cross-Sectional Regression Results}

To provide a detailed analysis for the hypotheses; Fama Macbeth (1973) cross-sectional regression will be used as it is one of the most commonly used tests in finance applications that provides an alternative way for running cross-sectional regression and the calculation of standard errors. By analyzing the t-statistics of each coefficient; useful insights will be revealed about the significance of the effect of different variables on the variability of expected return.

Capital gains overhang is a critical variable in this study and thus a detailed analysis is presented to analyze its relationship with other variables by regressing it on a set of firm explanatory variables. In the first model; explanatory variables include past cumulative returns over three periods; short-term (over the last 4 weeks), intermediate-term (between 5 weeks and 52 weeks), and long-term (between 53 weeks and 156 weeks), and size which is defined as lagged one-week logarithm of the market capitalization. In the second model, the average weekly turnover over the same three past periods is added to the set of explanatory variables.

Model 1: $g=a_{0}+a_{1} r_{t-4:-1}+a_{2} r_{t-52:-5}+a_{3} r_{t-156:-53}+a_{4} S_{t-1}$;

Model 2: $g=a_{0}+a_{1} r_{t-4:-1}+a_{2} r_{t-52:-5}+a_{3} r_{t-156:-53}+a_{4} S_{t-1}+a_{5} V_{-4:-1}+a_{6} V_{-52:-5}+a_{7} V_{-156:-53 .}$

Table 3. Average coefficients and t-statistics of capital gain regression (Model 1)

\begin{tabular}{llllllll}
\hline & $\mathrm{a}_{0}$ & $\mathrm{a}_{1}$ & $\mathrm{a}_{2}$ & $\mathrm{a}_{3}$ & $\mathrm{a}_{4}$ & $\mathrm{R}^{2}$ & ${\text { Adjusted } \mathrm{R}^{2}}^{\text {Parameter }}$ \\
\hline Patatistics & $-0.334^{* * *}$ & $1.014^{* * *}$ & $0.638^{* * *}$ & $0.203^{* * *}$ & $0.031^{* * *}$ & 0.514 & 0.467 \\
\hline
\end{tabular}

$g=a_{0}+a_{1} r_{t-4:-1}+a_{2} r_{t-52:-5}+a_{3} r_{t-156:-53}+a_{4} S_{t-1}$.

(*) denotes coefficients that are significant at $10 \%$ level according to t-statistics adjusted by the Newey-West procedure; (**) denotes coefficients that are significant at $5 \%$ level according to t-statistics adjusted by the Newey-West procedure; $(* * *)$ denotes coefficients that are significant at $1 \%$ level according to t-statistics adjusted by the Newey-West procedure.

Table 3 shows the results of the first regression model. The results show that about $51 \%$ of the variability in capital gains is explained by past cumulative returns and size. The coefficient of the short, intermediate and long cumulative past returns are $1.014,0.638$ and 0.203 respectively and they are all positive and statistically significant; hence it provides evidence towards supporting the first hypothesis that there is positive relation between past returns and capital gains overhang. However as can be seen that the magnitude of the relation is highest for the short-term cumulative return and lowest for long term cumulative return, this can be attributed to the argument of Grinblatt and Han (2005) regarding the declining effect of historical prices on reference price (the 
main determinant of capital gain), thus since recent prices have higher effect on reference price than old prices, this may explain the difference in magnitude between short and long terms cumulative returns.

Table 4 shows the results of the second regression model. This model explains about $62 \%$ of the variability in capital gains. The coefficients of short, intermediate and long horizons past turnover are $-3.841,-4.938$, and 9.290 respectively; where all of them are statistically significant. The negative coefficients of short and intermediate turnover indicates that as turnover increases, the reference price will get updated faster and hence catch up with the current price; and thus the capital gain which is the difference between reference price and market price will decrease. Finally the coefficient of size in both models tends to be positive and significant. This can be attributed to the growth of large stocks that may have lead them to achieve high past returns during different time horizons, and hence higher capital gains compared to small ones (Grinblatt \& Han, 2005).

The main aim of this study is to analyze whether disposition effect drives momentum in the Egyptian stock market. To provide an in-depth analysis of whether there is momentum in the Egyptian stock market and whether disposition drives this momentum; weekly return is regressed on capital gains overhang along with past cumulative return over short, intermediate and long time horizons controlling for size and turnover.

Table 4. Average coefficients and t-statistics of capital gain regression (Model 2)

\begin{tabular}{ccccccccccc}
\hline & $\mathrm{a}_{0}$ & $\mathrm{a}_{1}$ & \multicolumn{1}{c}{$\mathrm{a}_{2}$} & \multicolumn{1}{c}{$\mathrm{a}_{3}$} & \multicolumn{1}{c}{$\mathrm{a}_{4}$} & \multicolumn{1}{c}{$\mathrm{a}_{5}$} & \multicolumn{1}{c}{$\mathrm{a}_{6}$} & \multicolumn{1}{c}{$\mathrm{a}_{7}$} & $\mathrm{R}^{2}$ & Adj. $\mathrm{R}^{2}$ \\
\hline Parameter & $-0.354^{* * *}$ & $1.089^{* * *}$ & $0.611^{* * *}$ & $0.169^{* * *}$ & $0.035^{* * *}$ & $-3.841^{* *}$ & $-4.938^{* * *}$ & $9.290^{* * *}$ & 0.617 & 0.547 \\
t-statistics & -3.44 & 10.59 & 9.09 & 7.83 & 3.03 & -2.38 & -2.79 & 7.38 & & \\
\hline
\end{tabular}

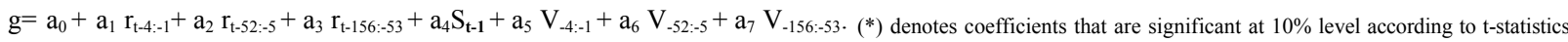
adjusted by the Newey-West procedure; $(* *)$ denotes coefficients that are significant at $5 \%$ level according to t-statistics adjusted by the Newey-West procedure; $(* * *)$ denotes coefficients that are significant at $1 \%$ level according to t-statistics adjusted by the Newey-West procedure.

To analyze the aforementioned hypotheses of this study four regression models are used, where a new variable is added in each model.

Model 1: $\mathrm{r}_{\mathrm{t}}=\mathrm{a}_{0}+\mathrm{a}_{1} \mathrm{r}_{\mathrm{t}-4:-1}+\mathrm{a}_{2} \mathrm{r}_{\mathrm{t}-52:-5}+\mathrm{a}_{3} \mathrm{r}_{\mathrm{t}-156:-53}$
Model 2: $\mathrm{r}_{\mathrm{t}}=\mathrm{a}_{0}+\mathrm{a}_{1} \mathrm{r}_{\mathrm{t}-4:-1}+\mathrm{a}_{2} \mathrm{r}_{\mathrm{t}-52:-5}+\mathrm{a}_{3} \mathrm{r}_{\mathrm{t}-156:-53}+\mathrm{a}_{4} \mathrm{~V}$
Model 3: $\mathrm{r}_{\mathrm{t}}=\mathrm{a}_{0}+\mathrm{a}_{1} \mathrm{r}_{\mathrm{t}-4:-1}+\mathrm{a}_{2} \mathrm{r}_{\mathrm{t}-52:-5}+\mathrm{a}_{3} \mathrm{r}_{\mathrm{t}-156:-53}+\mathrm{a}_{4} \mathrm{~V}+\mathrm{a}_{5} \mathrm{~S}_{\mathrm{t}-1}$
Model 4: $\mathrm{r}_{\mathrm{t}}=\mathrm{a}_{0}+\mathrm{a}_{1} \mathrm{r}_{\mathrm{t}-\mathrm{t}:-1}+\mathrm{a}_{2} \mathrm{r}_{\mathrm{t}-52:-5}+\mathrm{a}_{3} \mathrm{r}_{\mathrm{t}-156:-53}+\mathrm{a}_{4} \mathrm{~V}+\mathrm{a}_{5} \mathrm{~S}+\mathrm{a}_{6} \mathrm{~g}_{\mathrm{t}-1}$.

The results of the aforementioned four regression models are analyzed for the whole sample period, for January only, for December only and finally for February through November. The reason for studying the results over different months is to study if there is a seasonal pattern of momentum in stock returns in Egypt. Momentum in stock returns tends to be stronger and most effective in December. However, in January reversal in stock returns tends to be more effective (Jegadeesh \& Titman, 1993; Grinblatt \& Han, 2005). The seasonality in momentum in stock returns can be due to tax-loss selling that occurs in December, in addition to window dressing by institutional investors that occurs in quarter-ending months, and is more apparent in year end (Sias, 2007).

Table 5 reports the results of the first regression model. The coefficients of the past cumulative return over short, intermediate and long time horizons are statistically insignificant for all the months in the sample period, January only, February through November, and December only. Thus The Egyptian stock market does not show evidence of return predictability over the three aforementioned time horizons. This provides evidence against the third hypothesis that there is momentum in stock returns in the market. 
Table 5. Average coefficients and t-statistics of return regression (Model 1)

\begin{tabular}{|c|c|c|c|c|c|c|}
\hline & $\mathbf{a}_{0}$ & $\mathbf{a}_{1}$ & $\mathbf{a}_{2}$ & $\mathbf{a}_{3}$ & $\mathbf{R}^{2}$ & Adjusted $R^{2}$ \\
\hline \multirow[t]{2}{*}{ All } & 0.0020 & 0.0110 & -0.0030 & -0.0000 & 0.1630 & 0.1030 \\
\hline & $(0.7)$ & $(1.33)$ & $(-1.22)$ & $(-0.78)$ & & \\
\hline \multirow[t]{2}{*}{ January } & $0.020^{* *}$ & 0.000 & -0.000 & 0.001 & 0.154 & 0.091 \\
\hline & $(2.39)$ & $(0.01)$ & $(-0.04)$ & $(0.61)$ & & \\
\hline \multirow[t]{2}{*}{ February-November } & -0.000 & 0.011 & -0.003 & -0.001 & 0.162 & 0.101 \\
\hline & $(-0.19)$ & $(1.19)$ & $(-1.32)$ & $(-1.38)$ & & \\
\hline \multirow[t]{2}{*}{ December } & $0.010^{* *}$ & 0.009 & 0.001 & 0.001 & 0.187 & 0.127 \\
\hline & $(2.07)$ & $(0.55)$ & $(0.10)$ & $(0.70)$ & & \\
\hline
\end{tabular}

$r_{t}=a_{0}+a_{1} r_{t-4:-1}+a_{2} r_{t-52:-5}+a_{3} r_{t-156:-53}$.

$(*)$ denotes coefficients that are significant at $10 \%$ level according to t-statistics adjusted by the Newey-West procedure; $(* *)$ denotes coefficients that are significant at $5 \%$ level according to t-statistics adjusted by the Newey-West procedure; $(* * *)$ denotes coefficients that are significant at $1 \%$ level according to t-statistics adjusted by the Newey-West procedure.

Moreover these results contradict the results of previous research in developed markets; Jegadeesh and Titman (1993), Rouwenhorst (1998) and Grinblatt and Han (2005) among many others who find evidence supporting the existence of intermediate term momentum in developed markets. However, the results support the previous research about emerging markets which shows that there is no significant momentum profit in emerging markets (Rouwenhorst, 1999; Grundy \& Martin, 2001).

Another aspect that can be drawn from the above table is that there is no change in the significance of the coefficient of intermediate term momentum across different months analyzed which implies the absence of seasonal patterns in momentum in stock returns. This can be attributed to two main facts about the Egyptian stock market; first there is no capital gain tax in the market which is a main driver of observed seasonal pattern in many markets, second since window dressing effect is more common among institutional rather than individual investors, and the Egyptian market is dominated by the retail investors throughout the period 2004-2009, hence window dressing effect of institutional investors may not be sufficient to generate significant seasonal pattern in the market.

Table 6 and Table 7 show the results of the second and third regression model, where the average weekly turnover and the logarithm of market capitalization at the end of week (t-1) are added as control variables to control for volume and size effects respectively. The coefficient of average weekly turnover is insignificant and negative for the whole months analyzed. The negative sign of coefficient of turnover supports prior research that found that low (high) volume firms earn higher (lower) future return (Datar et al., 1998; Lee \& Swaminathan, 2000) which was attributed to liquidity effect. However the coefficient of average weekly turnover is significantly positive in January. This can be due to January effect, the phenomenon in which stocks, especially small ones, achieve large abnormal returns in January (Starks et al., 2006). Finally the coefficient of size is significantly negative except in December, this proves the existence of size effect in the Egyptian stock market (Banz, 1981),

Table 6. Average coefficients and t-statistics of return regression (Model 2)

\begin{tabular}{|c|c|c|c|c|c|c|c|}
\hline & $\mathbf{a}_{0}$ & $\mathbf{a}_{1}$ & $\mathbf{a}_{2}$ & $\mathbf{a}_{3}$ & $\mathbf{a}_{4}$ & $\mathbf{R}^{2}$ & Adjusted $R^{2}$ \\
\hline All & $\begin{array}{c}0.0020 \\
(0.7)\end{array}$ & $\begin{array}{l}0.008 \\
(0.97)\end{array}$ & $\begin{array}{c}-0.0020 \\
(-0.86)\end{array}$ & $\begin{array}{c}-0.0000 \\
(-0.45)\end{array}$ & $\begin{array}{l}-0.046 \\
(-1.00)\end{array}$ & 0.198 & 0.119 \\
\hline January & $\begin{array}{c}0.017 * \\
(2.00)\end{array}$ & $\begin{array}{l}0.007 \\
(0.22)\end{array}$ & $\begin{array}{l}-0.002 \\
(-0.28)\end{array}$ & $\begin{array}{l}0.001 \\
(0.54)\end{array}$ & $\begin{array}{c}0.382 * * \\
(2.13)\end{array}$ & 0.199 & 0.118 \\
\hline February-November & $\begin{array}{l}-0.000 \\
(-0.10)\end{array}$ & $\begin{array}{l}0.008 \\
(0.91)\end{array}$ & $\begin{array}{l}-0.002 \\
(-1.00)\end{array}$ & $\begin{array}{l}-0.000 \\
(-0.95)\end{array}$ & $\begin{array}{l}-0.065 \\
(-1.28)\end{array}$ & 0.196 & 0.117 \\
\hline December & $\begin{array}{l}0.010^{*} \\
(1.97)\end{array}$ & $\begin{array}{l}-0.004 \\
(-0.22)\end{array}$ & $\begin{array}{l}0.003 \\
(0.50)\end{array}$ & $\begin{array}{l}0.001 \\
(0.59)\end{array}$ & $\begin{array}{l}-0.183 \\
(-1.44)\end{array}$ & 0.221 & 0.143 \\
\hline
\end{tabular}

$r_{t}=a_{0}+a_{1} r_{t-4:-1}+a_{2} r_{t-52:-5}+a_{3} r_{t-156:-53}+a_{4} V$. 
Table 7. Average coefficients and t-statistics of return regression (Model 3)

\begin{tabular}{lcccccccc}
\hline & $\mathbf{a 0}$ & $\mathbf{a 1}$ & $\mathbf{a 2}$ & $\mathbf{a 3}$ & $\mathbf{a 4}$ & $\mathbf{a 5}$ & $\mathbf{R} 2$ & Adj. R2 \\
\hline All & $0.033^{* *}$ & 0.005 & -0.0020 & 0.0000 & -0.076 & $-0.003^{* *}$ & 0.238 & 0.142 \\
\multirow{2}{*}{ January } & $(2.47)$ & $(0.64)$ & $(-1.11)$ & $(0.16)$ & $(-1.62)$ & $(-2.57)$ & & \\
& $0.188^{* * *}$ & 0.005 & -0.002 & 0.001 & 0.018 & $-0.019^{* * *}$ & 0.257 & 0.161 \\
February-November & $(3.23)$ & $(0.15)$ & $(-0.45)$ & $(0.32)$ & $(0.08)$ & $(-3.04)$ & & \\
& $0.028^{*}$ & 0.005 & -0.003 & -0.000 & -0.081 & $-0.003^{* *}$ & 0.235 & 0.138 \\
December & $(1.92)$ & $(0.55)$ & $(-1.27)$ & $(-0.40)$ & $(-1.58)$ & $(-2.12)$ & & \\
& -0.030 & -0.001 & 0.003 & 0.002 & -0.084 & 0.004 & 0.263 & 0.168 \\
\hline
\end{tabular}

$r_{t}=a_{0}+a_{1} r_{t-4:-1}+a_{2} r_{t-52:-5}+a_{3} r_{t-156:-53}+a_{4} V+a_{5} S_{t-1}$.

$(*)$ denotes coefficients that are significant at $10 \%$ level according to t-statistics adjusted by the Newey-West procedure; $(* *)$ denotes coefficients that are significant at $5 \%$ level according to t-statistics adjusted by the Newey-West procedure; $(* * *)$ denotes coefficients that are significant at $1 \%$ level according to t-statistics adjusted by the Newey-West procedure.

Table 8 summarizes the results of the last regression model, where capital gain overhang is added as explanatory variable. First of all as can be seen that the coefficient of capital gain overhang is insignificant for all the months, January only and February through November, this implies that there is no positive relation between capital gains and expected return and that disposition effect does not drive momentum in the Egyptian stock market. Hence the results do not support the second hypothesis that there is a positive relation between capital gain overhang and expected returns, in addition the fourth hypothesis that disposition drives momentum is not supported.

The results of this study provide important and interesting facts about the Egyptian stock market that should be wrapped together to draw important implications about the market. First of all the results provide no evidence of return predictability in the Egyptian stock market, as there is no signs of intermediate term momentum in the market. The absence of return predictability in the market need not be a sign of market efficiency, a recent research testing the weak form efficiency in the Egyptian stock market by Al-Jafari and Altaee (2011) show that stock prices do not fully reflect all historical information and thus reject random walk theory at the weak form level, and show that prudent investors can earn abnormal return by using historical information about stock prices, trading volume, size and other market information.

Table 8. Average coefficients and t-statistics of return regression (Model 4)

\begin{tabular}{lccccccccc}
\hline & $\mathbf{a}_{\mathbf{0}}$ & $\mathbf{a}_{\mathbf{1}}$ & $\mathbf{a}_{\mathbf{2}}$ & $\mathbf{a}_{\mathbf{3}}$ & $\mathbf{a}_{\mathbf{4}}$ & $\mathbf{a}_{\mathbf{5}}$ & $\mathbf{a}_{\mathbf{6}}$ & $\mathbf{R}^{\mathbf{2}}$ & Adj. $^{\mathbf{2}}$ \\
\hline All & $0.034^{* *}$ & 0.004 & -0.001 & -0.000 & -0.066 & $-0.004^{* * *}$ & 0.000 & 0.263 & 0.149 \\
& $(2.51)$ & $(0.48)$ & $(-0.75)$ & $(-0.22)$ & $(-1.36)$ & $(-2.59)$ & $(0.14)$ & & \\
January & $0.186^{* * *}$ & 0.002 & -0.003 & 0.001 & 0.019 & $-0.019^{* * *}$ & 0.003 & 0.283 & 0.169 \\
& $(3.11)$ & $(0.07)$ & $(-0.51)$ & $(0.54)$ & $(0.08)$ & $(-2.92)$ & $(0.25)$ & & \\
February-November & $0.029^{* *}$ & 0.004 & -0.002 & -0.000 & -0.068 & $-0.003^{* *}$ & 0.001 & 0.261 & 0.146 \\
& $(2.00)$ & $(0.39)$ & $(-1.00)$ & $(-0.82)$ & $(-1.30)$ & $(-2.21)$ & $(0.30)$ & & \\
December & -0.034 & 0.002 & 0.005 & 0.002 & -0.084 & 0.005 & $-0.008^{*}$ & 0.276 & 0.161 \\
& $(-1.06)$ & $(0.13)$ & $(0.79)$ & $(1.02)$ & $(-0.64)$ & $(1.36)$ & $(-1.77)$ & & \\
\hline
\end{tabular}

$\mathrm{r}_{\mathrm{t}}=\mathrm{a}_{0}+\mathrm{a}_{1} \mathrm{r}_{\mathrm{t}-4:-1}+\mathrm{a}_{2} \mathrm{r}_{\mathrm{t}-52:-5}+\mathrm{a}_{3} \mathrm{r}_{\mathrm{t}-156:-53}+\mathrm{a}_{4} \mathrm{~V}+\mathrm{a}_{5} \mathrm{~S}_{\mathrm{t}-1}+\mathrm{a}_{6} \mathrm{~g}_{\mathrm{t}-1}$.

(*) denotes coefficients that are significant at $10 \%$ level according to t-statistics adjusted by the Newey-West procedure; (**) denotes coefficients that are significant at $5 \%$ level according to t-statistics adjusted by the Newey-West procedure; $(* * *)$ denotes coefficients that are significant at $1 \%$ level according to t-statistics adjusted by the Newey-West procedure.

The insignificant momentum in the market can be attributed to the arguments of Grinblatt and Han (2005) who state that for the disposition effect to drive momentum in the market there must be a mechanism for prices to converge to their fundamental values, otherwise under-reaction to information caused by disposition effect will persist and no momentum in stock returns will appear. In the same spirit, Debondt and Thaler (1985) show that long term reversal observed is due to overreaction hypothesis and subsequent correction. This means for return predictability to appear in the market there must be waves of correction for either under-reaction or overreaction to information. However the domination of retail investors who are subject to different biases in the Egyptian stock market, as well as the absence of different mechanisms that can help investors to correct any mispricing as the 
short sale mechanism may be the reasons behind the insignificant momentum in the market rather than the efficiency of the market.

Another aspect that may have resulted in the insignificance of momentum in the Egyptian stock market and the absence of the relation between disposition effect and momentum is the relation between momentum and market states in the Egyptian stock market. A recent study by Ismail (2012) showed that momentum in stock returns is stronger in up markets rather than down markets in the Egyptian stock market, and this supports Daniel et al. (1998) argument that momentum in stock returns is due to a combination of overconfidence and self attribution bias which are more apparent in up rather than down markets (Cooper et al., 2004). Since the sample period used in this study include both up and down market states, this may somehow explain the insignificance of momentum.

\section{Robustness Check}

In this section, the results of the four aforementioned regression models will be presented but after excluding the period of Financial Crisis from the sample to avoid any distortion that it may cause. The period that will be excluded from the analysis is the period from August 2008 to August 2009 which is the period that the crisis has its major impact on the Egyptian stock market.

\subsection{Fama Macbeth Regression: Disposition Effect and Momentum Results}

In this section the results of Fama Macbeth regression of the four models are analyzed to determine whether eliminating the period of Global Financial crisis affects the results. Table 9 shows the results of the first regression model that includes only the three past cumulative returns as explanatory variables. The results are somehow different from the full sample. The first aspect is the changes in the sign of intermediate term past cumulative returns as compared to the results of the full sample period in Table 5. In the full sample period, the coefficient of intermediate past cumulative was negative for all months, January only, and February through November. However by eliminating the distortion caused by the Global Financial Crisis, it is obvious that the coefficient of intermediate past cumulative return is positive but remained insignificant except in January it is insignificantly negative. The changes in the sign reflects the appearance of insignificant momentum profits, this can be backed to positive sentiment in the market in the sample period excluding the Financial Crisis, as was mentioned in Ismail (2012) that the momentum in stock returns in the Egyptian stock market is positive and significant in up markets.

Table 9. Robustness check: average coefficients and t-statistics of return regression (Model 1)

\begin{tabular}{|c|c|c|c|c|c|c|}
\hline & $\mathbf{a}_{0}$ & $\mathbf{a}_{1}$ & $\mathbf{a}_{2}$ & $\mathbf{a}_{3}$ & $\mathbf{R}^{2}$ & Adj. $R^{2}$ \\
\hline \multirow[t]{2}{*}{ All } & $0.0040^{*}$ & $0.0150 *$ & 0.003 & -0.0000 & 0.166 & 0.106 \\
\hline & $(1.78)$ & $(1.79)$ & $(0.82)$ & $(-0.83)$ & & \\
\hline \multirow[t]{2}{*}{ January } & $0.023 * *$ & 0.018 & -0.005 & -0.000 & 0.162 & 0.101 \\
\hline & $(2.73)$ & $(0.51)$ & $(-0.78)$ & $(-0.22)$ & & \\
\hline \multirow[t]{2}{*}{ February-November } & 0.002 & 0.015 & 0.002 & -0.001 & 0.163 & 0.102 \\
\hline & $(0.83)$ & $(1.53)$ & $(1.11)$ & $(-1.12)$ & & \\
\hline \multirow[t]{2}{*}{ December } & 0.008 & 0.019 & 0.002 & 0.001 & 0.200 & 0.143 \\
\hline & (1.53) & $(0.93)$ & $(0.30)$ & $(0.48)$ & & \\
\hline
\end{tabular}

$r_{t}=a_{0}+a_{1} r_{t-4:-1}+a_{2} r_{t-52:-5}+a_{3} r_{t-156:-53}$

$(*)$ denotes coefficients that are significant at $10 \%$ level according to t-statistics adjusted by the Newey-West procedure; $(* *)$ denotes coefficients that are significant at $5 \%$ level according to t-statistics adjusted by the Newey-West procedure; $(* * *)$ denotes coefficients that are significant at $1 \%$ level according to t-statistics adjusted by the Newey-West procedure.

Since the results are insignificant even in the sample that excludes the crisis, the results do not support the third hypothesis that there is momentum profit in the Egyptian stock market. In addition there are signs, although insignificant, of long term reversal as the coefficients of long term cumulative return is negative. These results can give weak support of overreaction hypothesis as an explanation of momentum in the market (Abinzano et al., 2010).

As for the seasonal effect, the results show that there is no sign of significant seasonal pattern as was observed in the results of Table 5. The sign of the coefficient of intermediate term past cumulative return is negative but still insignificant in January, however its coefficient is positive but remains insignificant in December. This weak seasonal pattern is mainly due to window dressing effect rather than tax-loss selling. 
Tables 10 and Table 11 show that results of the regression after adding average weekly turnover and logarithm of market capitalization as control variables. The coefficient of turnover is insignificant and negative for all the periods except for January the coefficient is significantly positive, which is mainly due to January effect, as losing stocks faces increased selling pressure at year-ends and they rebound back in January after this selling pressure dries. Thus there is a positive relation between past year volume and expected return in January (Starks et al., 2006). As for the size effect, the coefficient of size is significantly negative in all the periods except in December; this proves the existence of size effect in the Egyptian stock market which supports the results of Tables 6 and 7.

Table 10. Robustness check: average coefficients and t-statistics of return regression (Model 2)

\begin{tabular}{cccccccc}
\hline & $\mathbf{a}_{\mathbf{0}}$ & $\mathbf{a}_{\mathbf{1}}$ & $\mathbf{a}_{\mathbf{2}}$ & $\mathbf{a}_{\mathbf{3}}$ & $\mathbf{a}_{\mathbf{4}}$ & $\mathbf{R}^{2}$ & Adjusted $^{2}$ \\
\hline All & $0.004^{*}$ & 0.012 & 0.0020 & -0.0000 & -0.033 & 0.202 & 0.124 \\
& $(1.70)$ & $(1.34)$ & $(1.18)$ & $(-0.63)$ & $(-0.84)$ & & 0.128 \\
January & $0.019^{* *}$ & 0.024 & -0.007 & -0.000 & $0.435^{* *}$ & 0.207 & \\
& $(2.20)$ & $(0.67)$ & $(-0.99)$ & $(-0.29)$ & $(2.28)$ & & 0.119 \\
February-November & 0.002 & 0.012 & 0.002 & -0.000 & -0.054 & 0.198 & 0.161 \\
& $(0.85)$ & $(1.21)$ & $(1.45)$ & $(-0.83)$ & $(-1.33)$ & & 0.236 \\
\hline
\end{tabular}

$r_{t}=a_{0}+a_{1} r_{t-4:-1}+a_{2} r_{t-52:-5}+a_{3} r_{t-156:-53}+a_{4} V$.

(*) denotes coefficients that are significant at $10 \%$ level according to t-statistics adjusted by the Newey-West procedure; (**) denotes coefficients that are significant at $5 \%$ level according to t-statistics adjusted by the Newey-West procedure; $(* * *)$ denotes coefficients that are significant at $1 \%$ level according to t-statistics adjusted by the Newey-West procedure.

Table 11. Robustness check: average coefficients and t-statistics of return regression (Model 3)

\begin{tabular}{lcccccccc}
\hline & $\mathbf{a}_{\mathbf{0}}$ & $\mathbf{a}_{\mathbf{1}}$ & $\mathbf{a}_{\mathbf{2}}$ & $\mathbf{a}_{\mathbf{3}}$ & $\mathbf{a}_{\mathbf{4}}$ & $\mathbf{a}_{\mathbf{5}}$ & $\mathbf{R}^{\mathbf{2}}$ & Adj. $^{\mathbf{2}}$ \\
\hline All & $0.031^{* *}$ & 0.008 & 0.0020 & 0.0000 & -0.045 & $-0.003^{* *}$ & 0.242 & 0.146 \\
January & $(2.32)$ & $(0.94)$ & $(1.16)$ & $(0.08)$ & $(-1.24)$ & $(-2.24)$ & & \\
\multirow{3}{*}{ February-November } & $0.135^{* * *}$ & 0.017 & -0.004 & -0.001 & 0.246 & $-0.013^{* * *}$ & 0.249 & 0.153 \\
& $(3.40)$ & $(0.47)$ & $(-0.71)$ & $(-0.54)$ & $(1.45)$ & $(-3.32)$ & & \\
December & $0.028^{*}$ & 0.007 & 0.002 & -0.000 & -0.059 & $-0.003^{* *}$ & 0.238 & 0.141 \\
& $(1.88)$ & $(0.78)$ & $(1.36)$ & $(-0.08)$ & $(-1.56)$ & $(-1.91)$ & & \\
& -0.013 & 0.008 & 0.004 & 0.002 & -0.143 & 0.002 & 0.276 & 0.185 \\
\hline
\end{tabular}

$r_{t}=a_{0}+a_{1} r_{t-4:-1}+a_{2} r_{t-52:-5}+a_{3} r_{t-156:-53}+a_{4} V+a_{5} S_{t-1}$.

$(*)$ denotes coefficients that are significant at $10 \%$ level according to t-statistics adjusted by the Newey-West procedure; $(* *)$ denotes coefficients that are significant at $5 \%$ level according to t-statistics adjusted by the Newey-West procedure; $(* * *)$ denotes coefficients that are significant at $1 \%$ level according to t-statistics adjusted by the Newey-West procedure.

Table 12 shows the results of the regression model after adding capital gain overhang as a regressor. The results show that the coefficient of capital gain is insignificant and positive; this does not support the results of the second hypothesis that there is a positive relation between capital gain and expected return in the Egyptian stock market. In addition the results show that disposition effect does not drive momentum in the Egyptian stock market. Hence the results do not support the second and fourth hypotheses.

To conclude this section, first the results show some difference between the results of the full sample period and the results of the sample excluding the Global Financial Crisis. The most noticeable difference is in the results of the coefficient of intermediate term past cumulative returns where the signs of the coefficient turn form being negative for the full sample to positive but still insignificant for the sample excluding the crisis. The reason behind this change in the sign gives some evidence although a weak one of the relation between momentum and market states; momentum is stronger in up markets compared to down markets (Ismail, 2012). As for capital gain overhang, there was not a noticeable difference between its results in the two samples this shows that disposition effect is not the driver behind the change in the sign of intermediate term past cumulative return, along with the signs of weak long term reversal implied from the negative coefficient of the long term cumulative returns give support to overreaction as the driver of the observed weak momentum in the market in periods of up market (Abinzano et al., 2010). 
Table 12. Robustness check: average coefficients and t-statistics of return regression (Model 4)

\begin{tabular}{lccccccccc}
\hline & $\mathbf{a}_{\mathbf{0}}$ & $\mathbf{a}_{\mathbf{1}}$ & $\mathbf{a}_{\mathbf{2}}$ & $\mathbf{a}_{\mathbf{3}}$ & $\mathbf{a}_{\mathbf{4}}$ & $\mathbf{a}_{\mathbf{5}}$ & $\mathbf{a}_{\mathbf{6}}$ & $\mathbf{R}^{\mathbf{2}}$ & Adj. $^{\mathbf{2}}$ \\
\hline All & $0.031^{* *}$ & 0.006 & 0.001 & -0.000 & -0.042 & $-0.003^{* * *}$ & 0.001 & 0.266 & 0.151 \\
& $(2.30)$ & $(0.67)$ & $(0.89)$ & $(-0.29)$ & $(-1.14)$ & $(-2.25)$ & $(0.20)$ & & \\
January & $0.129^{* * *}$ & 0.012 & -0.004 & -0.000 & 0.253 & $-0.012^{* * *}$ & 0.004 & 0.277 & 0.163 \\
& $(3.31)$ & $(0.31)$ & $(-0.59)$ & $(-0.13)$ & $(1.64)$ & $(-3.18)$ & $(0.27)$ & & \\
\multirow{4}{*}{ February-November } & $0.029^{*}$ & 0.005 & 0.001 & -0.000 & -0.054 & $-0.003^{* *}$ & 0.001 & 0.263 & 0.147 \\
& $(1.93)$ & $(0.49)$ & $(0.88)$ & $(-0.64)$ & $(-1.45)$ & $(-2.00)$ & $(0.40)$ & & \\
December & -0.017 & 0.012 & 0.007 & 0.002 & -0.152 & 0.003 & -0.008 & 0.288 & 0.177 \\
& $(-0.45)$ & $(0.58)$ & $(0.85)$ & $(0.83)$ & $(-0.96)$ & $(0.64)$ & $(-1.66)$ & & \\
\hline
\end{tabular}

$r_{t}=a_{0}+a_{1} r_{t-4:-1}+a_{2} r_{t-52:-5}+a_{3} r_{t-156:-53}+a_{4} V+a_{5} S_{t-1}+a_{6} g_{t-1}$

(*) denotes coefficients that are significant at $10 \%$ level according to t-statistics adjusted by the Newey-West procedure; (**) denotes coefficients that are significant at $5 \%$ level according to $t$-statistics adjusted by the Newey-West procedure; $(* * *)$ denotes coefficients that are significant at $1 \%$ level according to t-statistics adjusted by the Newey-West procedure.

\section{Conclusion, Limitations, and Recommendations}

Momentum in stock returns is one of the puzzling phenomena in the financial markets that have attracted the attention of both practitioners as well as academics. However, despite the plenty of research works analyzing momentum to either prove its existence or explain it in both developed and emerging markets, a considerable lack of research studies was recognized in the Middle East in general and the Egyptian stock market in particular. This gap in research signifies the importance of this study that aims at analyzing whether there is momentum in stock returns in the Egyptian stock market and whether disposition effect, behavioral bias, drives momentum using Grinblatt and Han (2005) model.

The results of empirical analysis show that there is no significant momentum profit in the Egyptian stock market. These results agree with previous research about emerging market that show that there is no significant momentum (Rouwenhorst, 1999). In addition the results show that there is neither persistent nor significant positive relation between capital gain overhang and future returns in the Egyptian stock market and this show that disposition effect does not drive momentum in the Egyptian stock market which contradicts the results of Grinblatt and Han (2005) and Frazzini (2006) who show that there is a significant positive relation between capital gains overhang and expected returns in developed markets.

Several practical implications can be derived from these results. First, the results show that relevant strength strategies do not earn abnormal return in the Egyptian stock market. In addition the results can be taken as a sign of inefficiency of the market as the ability of disposition effect to generate momentum in the market requires correcting mechanism to help prices revert to their fundamental values which in turn leads to the observed return predictability (Grinblatt \& Han, 2005), but if these mechanisms are not available in the market there will be no predictability in stock prices and the under-reaction caused by the existence of disposition investors will persist.

Since the Egyptian stock market is an emerging market that is dominated by retail investors, and that faces a considerable lack of different trading mechanism like short-selling, this may be a reason behind the results of this study. However an overview about the Egyptian market shows that year 2010-2011 witnessed an increase in the number of institutional investors in the market, in addition the Egyptian Financial Supervisory Authority (EFSA) approved on December, 2011 rules for margin trading and same day short selling as new trading methods in the Egyptian stock market (Abdellatif, 2011). These changes may have an effect on momentum in stock returns and on the relation between disposition effect and momentum and hence this creates a need to study whether disposition effect drives momentum in recent years in the Egyptian stocks.

The main limitation in this study is the unavailability of historical data, in addition to the limited number of active stocks in the Egyptian stock market. The limited number of years available affected the calculation of reference price that will in turn affect the calculation of capital gain overhang. Grinblatt and Han (2005) used five years of historical data to calculate the reference price, however due to the unavailability of data only three years of historical data were used to calculate the reference price in this thesis. However this will not affect the results as Grinblatt and Han (2005) mentioned that using three, five, or seven years of historical data to calculate the reference price yield similar results. in addition the limited number of active companies in the market compared to other markets where the model has been previously applied poses another limitation. 
The results of this research open new areas that can be investigated and studied about the Egyptian stock market. In the spirit of the results of this study, a detailed study about momentum and contrarian strategies about the Egyptian stock market over different formation and holding periods and in different market states is required to analyze the effect of market states on the profitability of momentum. Also as was mentioned above, the new trading mechanisms and the increase in the number of institutional investors creates a need to study the effect of these changes on the profitability of momentum in the stock returns as these changes help in correcting the mispricing that may occur due to disposition effect or other behavioral biases and hence generate return predictability.

\section{References}

Abdellatif, R. (2011). Egypt market regulator approves margin trading, short selling rules. Daily News Egypt. Retrieved

from

http://www.thedailynewsegypt.com/stock-market/egypt-market-regulator-approves-margin-trading-short-sel ling-rules.html

Al-Jafari, M., \& Altaee, H. (2011). Testing the random walk behavior and efficiency of the Egyptian equity market. Journal of Money, Investment and Banking, 22, 132-146.

Ansari, V., \& Khan, S. (2012). Momentum anomaly: Evidence from India. Managerial Finance, 38(2), 206-223. http://dx.doi.org/10.1108/03074351211193730

Banz, R. (1981). The relationship between return and market value of common stocks. Journal of Financial Economics, 9(1), 3-18. http://dx.doi.org/10.1016/0304-405X(81)90018-0

Barberis, N., Shleifer, A., \& Vishny, R. (1998). A model of investor sentiment. Journal of Financial Economics, 49(3), 307-343. http://dx.doi.org/10.1016/S0304-405X(98)00027-0

Cao, X. (2010). Disposition effect and momentum based on prospect theory/mental accounting in the Chinese Stock Market. Master thesis, Auckland University of Technology: China.

Chan, L. K. C, Jegadeesh, N., \& Lakonishok, J. (1996). Momentum strategies. Journal of Finance, 51(5), 1681-1713. http://dx.doi.org/10.1111/j.1540-6261.1996.tb05222.x

Conard, J., \& Kaul, G. (1993). Long-term market overreaction or biases in computed returns? Journal of Finance, 48(1), 39-63. http://dx.doi.org/10.1111/j.1540-6261.1993.tb04701.x

Cooper, M., Gutierrez, Jr. R., \& Hameed, A. (2004). Market states and momentum. Journal of Finance, 59(3), 1345-1365. http://dx.doi.org/10.1111/j.1540-6261.2004.00665.x

Dahr, R., \& Zhu, N. (2006). Up close and personal: Investor sophistication and the disposition effect. Management Science, 52(5), 726-740. http://dx.doi.org/10.1287/mnsc.1040.0473

Daniel, K., Hirshleifer, D., \& Subrahmanyam, A. (1998). Investor psychology and security market under- and overreactions. Journal of Finance, 53(6), 1839-1885. http://dx.doi.org/10.1111/0022-1082.00077

Debondt, W. F. M., \& Thaler, R. (1985). Does the stock market overreact. Journal of Finance, 40(3), 793-805. http://dx.doi.org/10.1111/j.1540-6261.1985.tb05004.x

Fama, E. (1970). Efficient capital markets: A review of theory and empirical work. Journal of Finance, 25(2), 383-417. http://dx.doi.org/10.2307/2325486

Fama, E., \& Macbeth, J. (1973). Risk, return and equilibrium: Empirical test. Journal of political Economy, 81(3), 607-636. http://dx.doi.org/10.1086/260061

Frazzini, A. (2006). The disposition effect and under-reaction to news. Journal of Finance, 61(4), 2017-2046. http://dx.doi.org/10.1111/j.1540-6261.2006.00896.x

Griffin, J., Ji, X., \& Martin, S. (2003). Momentum investing and business cycle risk: Evidence from pole to pole. Journal of Finance, 58(6), 2515-2547. http://dx.doi.org/10.1046/j.1540-6261.2003.00614.x

Grinblatt, M., \& Han, B. (2002). The disposition effect and momentum. NBER Working Paper, 8734.

Grinblatt, M., \& Han, B. (2005). Prospect theory, mental accounting and momentum. Journal of Financial Economics, 78(2), 311-339. http://dx.doi.org/10.1016/j.jfineco.2004.10.006

Grundy, B., \& Martin, J. (2001). Understanding the nature of the risks and the sources of the rewards to momentum investing. Review of Financial Studies, 14(1), 29-78. http://dx.doi.org/10.1093/rfs/14.1.29

Hameed, A., \& Kusnadi, Y. (2002). Momentum strategies: Evidence from pacific basin stock markets. Journal of 
Financial Research, 25(3), 383-397. http://dx.doi.org/10.1111/1475-6803.00025

Hong, H., \& Stein, J. C. (1999). A unified theory of under-reaction, momentum trading, and overreaction in asset markets. Journal of Finance, 54(6), 143-2184. http://dx.doi.org/10.1111/0022-1082.00184

Hurn, S., \& Pavlov, V. (2003). Momentum in Australian stock returns. Australian Journal of Management, 28(2), 141-155. http://dx.doi.org/10.1177/031289620302800202

Ismail, E. (2012). Do momentum and contrarian profits exist in the Egyptian stock market? International Research Journal of Finance and Economics, 87, 48-72.

Jegadeesh, N. (1990). Evidence of predictable behavior of security returns. Journal of Finance, 45(3), 881-898. http://dx.doi.org/10.1111/j.1540-6261.1990.tb05110.x

Jegadeesh, N., \& Titman, S. (1993). Returns to buying winners and selling losers: Implications for stock market efficiency. Journal of Finance, 48(1), 65-91. http://dx.doi.org/10.1111/j.1540-6261.1993.tb04702.x

Jegadeesh, N., \& Titman, S. (2001). Profitability of momentum strategies: An evaluation of alternative explanations. Journal of Finance, 56(2), 699-720. http://dx.doi.org/10.1111/0022-1082.00342

Lee, C., \& Swaminathan, B. (2000). Price momentum and trading volume. Journal of Finance, 55(5), 2017-2070. http://dx.doi.org/10.1111/j.1540-6261.1990.tb05110.x

Lehmann, B. (1990). Fads, martingales, and market efficiency. Quarterly Journal of Economics, 105(1), 1-28. http://dx.doi.org/10.2307/2937816

Lewellen, J. (2002). Momentum and autocorrelation in stock returns. Review of Financial Studies, 15(2), 533-564. http://dx.doi.org/10.1093/rfs/15.2.533

Mecagni, M., \& Sourial, M. S. (1999). The Egyptian stock market: Efficiency tests and volatility effects. IMF Working Paper \# WP/99/48, Washington, D.C.

Ministry of Finance. (2010). Egyptian economic monitor. Arab Republic of Egypt: Ministryof Finance. Retrieved from http://www.mof.gov.eg/MOFGallerySource/English/PDF/Monitor_Dec_web.pdf

Odean, T. (1998). Are investors reluctant to realize their losses? Journal of Finance, 53(5), 1775-1797. http://dx.doi.org/10.1111/0022-1082.00072

Rouwenhorst, K. G. (1998). International momentum strategies. Journal of Finance, 53(1), 267-284. http://dx.doi.org/10.1111/0022-1082.95722

Rouwenhorst, K. G. (1999). Local return factors and turnover in emerging stock markets. Journal of Finance, 54(4), 1439-1464. http://dx.doi.org/10.1111/0022-1082.00151

Shapira, Z., \& Venezia, I. (2001). Patterns of behavior of professionally manages and independent investors. Journal of Banking and Finance, 25(8), 1573-1587. http://dx.doi.org/10.1016/S0378-4266(00)00139-4

Shefrin, H., \& Statman, M. (1985). The disposition to sell winners too early and ride losers too long. Journal of Finance, 40(3), 777-790. http://dx.doi.org/10.1111/j.1540-6261.1985.tb05002.x

Shleifer, A. (2000). Inefficient markets: An introduction to behavioral finance (1st ed.). USA: Oxford University Press. http://dx.doi.org/10.1093/0198292279.001.0001

Sias, R. (2007). Window-dressing, tax-loss selling, and momentum profit seasonality. Financial Analysts Journal, 63(2), 48-54. http://dx.doi.org/10.2469/faj.v63.n2.4521

Starks, L., Yong, L., \& Zheng, L. (2006). Tax-loss selling and the january effect: Evidence from municipal bond closed-end funds. Journal of Finance, 61(6), 3049-3067. http://dx.doi.org/10.1111/j.1540-6261.2006.01011.x

Van der Hart, J., De Zwart, G., \& Van Dijk, D. (2005). The success of stock selection strategies in emerging markets: Is it risk or behavioral bias? Emerging Markets Review, 6(3), 238-262. http://dx.doi.org/10.1016/j.ememar.2005.05.002

Wang, C. (2004). Relative strength strategies in China's stock market: 1994-2000. Pacific-Basin Finance Journal, 12(2), 159-177. http://dx.doi.org/10.1016/S0927-538X(03)00043-X 


\section{Copyrights}

Copyright for this article is retained by the author(s), with first publication rights granted to the journal.

This is an open-access article distributed under the terms and conditions of the Creative Commons Attribution license (http://creativecommons.org/licenses/by/3.0/). 